\title{
SYLVIA TOWNSEND WARNER'S LETTERS TO PETER PEARS
}

Before Sylvia first met Britten and Pears at the home of Reynolds and Janet Stone in Litton Cheney she had long been an admirer of their work. In February 1954, returning from a concert in Dorchester that included Britten's new cycle of Hardy poems, she wrote in her diary: 'Pears singing very well ... a Schubert I did'nt know, Sprach der Liebe, most beautifully phrazed ... As for Britten, a head with no chin, a pounce like a weasel, and a total attentiveness and identification with the music.'

When, in 1970, she concieved the idea of donating her collection of Craske paintings and needleworks to Snape Maltings as a memorial to Valentine, she broached the idea in a letter to Peter Pears who suggested an exhibition in Aldeburgh the following year. So began a correspondence that quickly blossomed into a lasting friendship and culminated in the programme of readings and music in her honour organized by Pears as part of the 1977 Aldeburgh festival.

The friendship, refered to only briefly in Claire Harman's biography and about which Christopher Headington's Life of Pears is curiously silent, grew out of a shared love of music, an enthusiasm for the Craske embroideries and, latterly, the loss of a life-long partner (Britten) that brought back painful memories for Sylvia. The following is a selection from the forty five unpublished letters by Sylvia held in the BrittenPears library at the Red House in Aldeburgh. 


\section{Undated (Spring 1970)}

Dear Peter Pears,

When I came home this afternoon I looked at the Craske pictures with an unclouded pleasure - as I have not been able to see them for many months. There you are, I thought, with your future assured; you will have a good home in your native climate, and be honoured in your own country.

Thanks to you, what had been becoming a careworn responsibility is restored to a pride and a pleasure.

And this would be not quite so if I had not seen that you really liked them. I can assure you that you will like them better and better. They will be immensely enhanced in the sharpened light of a seaboard sky. I don't know if there is a word for visual acoustics, but I know the condition exists.

Meanwhile, I have been reckoning up the other Craskeowners who will loan their pictures for the exhibition; and, if my persuasions can do anything, will bequeath them to your gallery.

I will let you know how things go on. And again, thank you for making such a happy and glorious day for me.

Yours sincerely,

Sylvia Townsend Warner

$19: v: 1970$

Dear Peter,

Eight more Craskes for sure: and three I hope to bring down but I haven't heard from the owners yet. One of these we might have seen while you were here. John Betjeman bought a large and fine one, couldn't for some reason fit it into his car and left it behind at the Old Rectory. All this many years ago, but Reynolds feels sure it's safely somewhere and will look for it next week (they are just off to one of their stately pleasure-dome visits).

There are some good ones in American ownership. I think the best chance for these would be if you enquired about 
them. The owner is (A) a snob and (B) doesn't like me (it might be better if you have heard of her from Mrs Mark Lubbock, who is lending for the show).

Address, till middle of June:

Miss E Wade White

44B Park Town, Oxford.

And the same Mrs Mark Lubbock who writes articles for Country Life would like to write an article about Craske's work, to come out at an appropriate moment in 1971. Shall we say Yes?

And here is Laura Craske's life of him which she wrote for Valentine, and Valentine's notes. KEEP.

Anise is the basis of that revolting French liqueur. I think the botanical name is pimpinella. You see, I have read your American Holiday. It delighted me: the cottage-loaf wife, and all that generous happiness. I have a passion for people being happy. One of the worst things about bereavement is that it makes one mistrust one's capacity for enjoying - which is impious ingratitude for the past. You were very restorative while we sat in the garden. I had hoped you might admire the Craskes but I had not forseen that I would get a new friend by it. Please come again if you are anywhere near by. There will always be coffee, and soup-of-the-day, and a very welcoming

Sylvia

$10: v i: 1970$

Dear Peter,

This is no moment to write to you, when you are in full Festival. But I am so excited with the latest Craske development that write I must or die of tight-lacing.

There is a LARGE silkwork of the North Norfolk coast in the Glan[d]ford Shell Museum; and the son of the East Dereham doctor has three silkworks (and some water colours) which he will be delighted to lend us for the show. He is full of goodwill. If you should ever have time it might be a good plan if you went to East Dereham to see what they are like. 
Meanwhile I have also secured a large woolwork of a fishing village (pure Peter Grimes, with the parson posting a letter in a central orb of a red pillarbox: I know this one well, for it was ours for a while) and a strange embroidered Zodiac of fish. These are in the Scilly Isles. Not counting the East Dereham lot or the Shell Museum's or the Dunkirk in Norwich, we are now sure of 26.

And we haven't so far touched the USA, though I shall now write to Betty Parsons who bought a Craske and keeps a picture gallery in NYC.

There! I have cut my laces and feel much better.

Love,

Sylvia

$3: x i: 1971$

Dear Peter,

I am glad I was at the Red House when you got home and that you are pleased with The Innocent and the Guilty, and wrote so kindly to tell me so. Please be pleased with the story in The Garland of Straw called The Song of Songs. Mr Devereux Pitfield is still dear to me though I invented him seizing on semibreves so long ago.

And thank you for the postcard of the Chartres Shepherds. How fortunate that their sculptor knew about The Winter's Tale so long before anyone else did.

As you will know by your own garden, roses obstinately think it is still summer (so do strawberries - an amiable foible). Robert the Devil will not be ready to transplant for some time yet, not till mid-November I think. If you still toy with the idea of coming here to work on that volume of English songs (which would delight me), avoid Dec. 6th to 9th when I have a visitor. R. le D. and the clump of sorrel could be transplanted at any time before March unless the ground is too frozen to dig them out of it.

Paul Nordoff was here a couple of weeks ago with tapes of his therapy by music sessions. He was very happy about Ben's 
preface to the book. So was I. So will a great many readers be, for the book is selling well. It - the preface - is as convincing as if Ben had written it as music. That is what I feel about Ben's music. I believe every note of it.

Much love to you both, Sylvia.

$14:$ iv $: 1972$

Dear Peter,

I have heard of another Craske. According to Janet Machen who reported it, it is a very good one: a ship coming into harbour, a man watching it from the quay: colouring mainly grey and brown, size, she thinks, about 22" x 18 ". It belongs to Elizabeth Muntz, the sculptress, and is at Chaldon, about 20 miles from here. Janet is emphatic that it ought to go to the Maltings. She fished about Miss Muntz's intentions, but could not get at them (she, E. M., is old and slightly gaga.) If you should come this way, perhaps you might visit E. M. and exercise your arts and charms.

Visit me too, I hope.

Love to you both

Sylvia

$22:$ iv $: 1972$

Dear Peter,

I have put a ring of roses round July 13th. It will be a great pleasure to see you. I hope you will stay the night and we can breakfast in the garden. Two separate hopes. I hope you can stay the night wherever we may breakfast.

Elizabeth Muntz was a pupil of Dobsons. She did very good lettering and deplorable sculpture - like over-sweetened suet puddings.

I have just come back from Denmark where I stayed with Paul and Clive (Therapy by Music). They are in a modern 
house by old Bruhl. I particularly admired the taps and handles. The house was like a technological rabbit-hutch not my idea of architecture.

Love from

Sylvia

$19:$ iv $: 72$

Come again! - endeared Peter and don't let the next interval be such a long one.

You are the most comfortable of visitors, the most reviving, the most reassuring. You make me feel as stroked as the cats. I bless the fortune which brought you here to look at the Craskes and began our friendship. Come again!

With love,

Sylvia

PS You are very good for me.

$14: x: 72$

Dearest Peter,

Summoned by crumpets, I forgot to show you the Petit Larousse picture of mushrooms, comestibles et mortels au foxiques.

Do NOT eat any bright orange mushrooms with spots on them. None of them is advisable and one is mortal. It has a frill halfway down its leg like Charles II, for further identification.

Thank you for yesterday

With love

Sylvia 
$1: v: 1974$

Dearest Peter,

I have thought of you and thought of you; and each time with a sadder heart. One climbs up a steep hill, and calls it Hope, and from the summit looks down and recognises the prospect of descent stretching in front of one.

All vital people die of a wound - so it seems to me. The fire at the Maltings, the shock of the news, the rush of adrenalin, the excitement and resolution on the heels of shock: that may be the true history of Ben's heart.

The last news I heard of you was when I was at Boywoods[?] not long after you had stayed there; sitting in the sun and considering amendations to Death in Venice. It has been a picture in my mind ever since.

I listened to your reading of the Sonnets. They could not have been more perfectly, more unaffectedly read. And a little before then I listened to Ben's conducting of The Midsummer Night's Dream and was overwhelmed by the mysterious majesty of the Epilogue, that glimmer in the dusk. And I remembered the old woman who invented omelettes and was asked her secret. Simple, she said: just new-laid eggs and fresh butter and a few herbs out of my garden. Ben's recipe to the life. Not a stale note in all his music. Give him my love and my thanks.

As for me, I am well, and, to my surprise for the last year I have been writing story after story in a new way; my posthumous manner. There is one in this week's New Yorker, if you would care to know more. The river flows on, with willows newly green on its banks and hail stones at the moment breaking its surface.

Your room will always be ready for you. Your rooms indeed, for Valentine's sitting room, with two views of the river and walls of books, would be yours if you needed to be by yourself. And you know how happy I would be to see you.

True love to you both

Sylvia 
$22: v: 1974$

Dearest Peter,

The postman has just delivered your letter. He must have known how happy it would make me, for he went away whistling (it should have been Dalla Sua Pace, but he was in fact developing a theme of his own).

Ben is 'quite a little better', you say; and you are hoping. I will hope too, and be thankful to you for your letter which releases me into hope. This is the time of year to get better in, when those confimatory swallows have arrived and one can smell lilacs and think of roses. And of strawberries. God would be a very bare-bones-praise God not to think of strawberries. I hope your asparagus thrives.

You will see by the nonsense I am writing what a lift your letter has given me.

It will be too long to wait for that next book by STW, so tomorrow I will post you two of the latest $N$. Y. stories.

My true love to you both

Sylvia

$21: i: 1976$

Dear Peter,

Benedictus qui venit this is being a lovely week what with you and Dowland. I realised listening to you in the Monday concert that why no one can sing the lutanist songs as you can is that you sing the words as poetry.

I am so much Time's eldest - that I must be one of the first people who knew Book One. Edmund Fellowes used to visit my flat in Bayswater on the way to Paddington Station, and I remember the afternoon when he brought his first transcriptions - red in the face with joy and excitement. The discoverer's first view of an unknown ocean.

You and Dowland have revived my hope for mankind. Every friend I have in New York had been telling me about 
the Bergman film of The Magic Flute, and all of them, even the intelligent ones used the same word; and the word was charming. I went about hissing kitsch like a nest of serpents. When I produce The Flute I shall aim to go back to the original theatre; garret, rather dirty and reach-me-down, with quantities of Woolworth jewellery for the Queen of the Night.

I'm afraid there won't be much me in the New Yorker for the present. I am working at a collected volume of the Elfin stories, revising and checking, and till that is off my back, no writing to lead me astray.

My love, my thanks, to you both

Sylvia

$10: i i: 1976$

Dear Peter,

Thank you for the Watteau fly-swatter that came this morning. I didn't know it, and I love it.

On the heels of that I had a second encounter with you; the pickled boys on the radio 3 Britten series they are doing this week. It was such a pleasure to hear you mounting that common chord; and to meet those bad children of Albert Herring atesting at a miracle.

No, the river didn't freeze. The worst thing was a biting, blighting wind; which the BBC weather prophets assured us came straight from the Arctic - in case we thought it was an inferior article straight from the grocer's refridgerator. I expect your winds were even colder, blowing over that lake.

I hope you are glad to be home. I wish you would be glad to come here, later on. Daffodils? Strawberries? A seasonal soup? I often talk to you in my mind.

Give my love to Ben and to yourself

Sylvia 
$1:$ iii $: 1976$

Dear Peter,

Your letter came this morning; and with it all the crocuses opened and bees hurried into the crocuses.

It is a lovely and glorious plan. I am primmed up with Majestic Pride. Thank you very much for thinking of it.

I will think slowly about what it could be. But I know instantly one thing I would like: the Fire and Water music in the Magic Flute. I took myself to hear the Flute in 1912(?) Claire Dox was singing; she stood motionless as an urn through Ach ich fuhl's. I was hooked then, and with the Fire and Water music I was Mozart's for life. If I heard it on a tin whistle and a dustpan lid I would be on my knees.

I was meaning to write to you with a piece of serendipity: fascinating and not of the slightest importance - did you know that Marvellina's second aria in Figaro, the one about animals being so much kinder to their mates than human's are, comes straight out of Aristo? clever da Ponte!

Much love to you both

Sylvia

$14:$ viii : 1976

Dearest Peter,

About one thing I am categorical.

You must read my poems; and a story if you please. I have listened to you reading poetry on the $3 \mathrm{rd}$, and realised the quality of poetry with breath control instead of the usual puffand-pant. I think you have King Duffus about the river full of trees. You would make that river flow. There is a volume of the Elfin stories due out early next year, and I will send you a copy. One about the power of choral singing - it moved a Welsh mountain - might be suitable.

My dear, when I proclaimed my love for the M.F. Fire and Water music, I was thinking in terms of Desert Island Discs. 
For in my most high flown mood I would not expect an orchestra, a chorus, and two expert soloists for five minutes.

I would like to hear the Alan Bush cycle in real life. I only heard it by sight. I am not overly attached to the John Ireland settings. Would it be possible to have the second and fourth of Paul Nordoff's Lost Summer? The other two don't work out with a piano accompaniment very satisfactorily. Too many notes, like wasps round the singer.

And please, one or two madrigals. I can never hear Wilbye often enough. And will you sing? The Mozart Masonic Cantata? I leave the choice to you.

I seem an ungrateful warthog not to have written before, I was temporarily a ruin from breathing nothing but dry air.

My love to Ben, my love to you

Sylvia

Of course, if you could come and talk it over, I still make very good soups.

$27: x i: 1976$

Dearest Peter,

My mind often pauses to sit with you at Ben's bedside. His death after these years of hope and disappointment is like a long-prepared enharmonic modulation. He will pass from making music to being music; though it must wring your heart - it does mine - to think of the music he will carry with him.

About Paul Nordoff. It is the Lament for the Makers. Paul is in a German hospital, dying. I had a leave-taking letter from him a fortnight ago. It is so long since he had a settled place that I don't know where to seek his manuscripts. The two songs I had in mind are in Lost Summer, voice and orchestra. If I can trace the score I could transcribe them well enough for it to be possible to make a piano version. His son, in Maine, may know its whereabouts. I will ask him. All I have here is a setting, voice and piano, of a poem of mine called The Arrival. This I will send off tomorrow. 
The Fire and Water Music would be ideal loud-speakered. It belongs to disembodiment. And you, you, and only you, must read the poems. (Alan Bush, I remember, set some of them). And may there be something of Ben's.

It is strange to be planning for such a benefit ahead.

With my love

Sylvia

$30:$ iii $: 78$

Dear Peter,

This may be my last letter. I want to send you my love and my thanks for all the beauty that your music has meant to me.

And keep an eye on the Craskes.

I've just been told that your singing of 'Die schone Mullerin' with Murray Perraia accompanying, was beautiful, deeply felt and a hymn to Ben. Sing on, my darling.

My love,

Sylvia

\section{Copyrighted image removed}

John Craske's needlework Rescue by Breeches Buoy, part of the STW Bequest. 
Partly as a result of the visit to Snape Maltings last September by members of the Society, Aldeburgh Productions has dusted off its Craskes ready for an exhibition in the Concert Hall Gallery this autumn. Half the paintings have been restored and all have been reframed. The result is a handsome display together with information panels that tell the story of Craske's life, his discovery by Valentine and Sylvia's bequest.

This summer a selection of needleworks has been on dispay in Sheringham Museum including a work not previously exhibited; an oval composition of lighthouse, lifeboat and border text: 'With Christ in the vessel w'ell smile at the storm'. As Sylvia had always hoped, Craske is at last being 'honoured in [his] own country'. 